\title{
Reactive natural phosphate and nitrogen fertilizers in Marandu grass fertilization
}

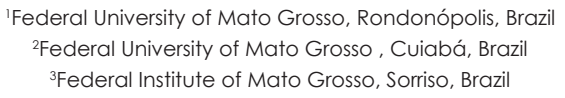

Carlos Eduardo Avelino Cabral"*, Luciano da Silva Cabral', Edna Maria Bonfim-Silva², Kassio dos Santos Carvalho ${ }^{3}$, Joadil Gonçalves de Abreu', Carla Heloisa Avelino Cabral ${ }^{2}$

\begin{abstract}
This study aimed to identify a nitrogen fertilizer in order to allow the use of reactive natural phosphate (phosphate rock) in the fertilization of Marandu grass (palisade grass cv. Marandu) in a sandy clayey Oxisol with low phosphorus content. The experiment was performed in a plant nursery at the Federal University of Mato Grosso (UFMT), in a completely randomized experimental design, in a split-plot scheme, with eight replications. The plots consisted of six fertilization treatments of the Marandu grass (Brachiaria brizantha cv. Marandu), divided into four treatments applied after liming and two treatments without liming. Treatments in the presence of liming were: single superphosphate and urea, single superphosphate and ammonium sulfate, urea and reactive natural phosphate, reactive natural phosphate and ammonium sulfate. Treatments without liming were: reactive natural phosphate and urea, reactive natural phosphate and ammonium sulfate. For this experiment, three growth times were evaluated. Ammonium sulfate allows the use of reactive natural phosphate in the fertilization of the Marandu grass even after liming, whilst urea does not provide sufficient acidity.
\end{abstract}

Keywords: Brachiaria brizantha, phosphorus, urea, ammonium sulfate.

\section{Introduction}

Phosphorus possesses a strong interaction with the soil, what might imply in a lower fertilization efficacy or the use of higher dosages of this nutrient. In soils rich in iron oxide, such as the Oxisols, there is an increase in the phosphorus forms more strongly linked to these minerals (Eberhardt et al., 2008; Cessa et al., 2009), due to the elevated point of zero charge. For these reasons, higher dosages of phosphate fertilizers must be recommended in these soils.

In this manner, the reactive natural phosphate (phosphate rock) might be an alternative in the fertilization of forage grasses, reducing the phosphorus fixation through its slow solubilization, besides reducing the cost of the phosphate fertilization. However, the solubilization of this fertilizer occurs in acid soils (Guedes et al., 2009). Therefore, it is recommended that the reactive natural phosphate be applied to the soil before or along with liming, although in both situations a lower efficacy has been observed than with soluble fertilizers. (Kaminski \& Mello, 1984).

A possible manner of utilizing the reactive natural phosphate after liming is through associating this fertilizer with the nitrogen fertilization. Ammonium nitrification in the soil contributes to the acidification of its upper layer, mainly when high dosages of nitrogen fertilizers 
are applied. Considering that the nitrogen is a more required nutrient in the maintenance fertilization of forage grasses, it might be viable to identify a nitrogen fertilizer which allows the use of the reactive natural phosphate after liming. Although every nitrogen fertilizer does reduce the $\mathrm{pH}$ of the soil through nitrification, the ammonium sulfate provides a higher acidification than urea, (Sangoi et al. 2009; Sousa e Silva, 2009, Delbem et al., 2011), what might optimize the use of the reactive natural phosphate. In this manner, the aim was to identify a nitrogen fertilizer which allows the use of reactive natural phosphate in the fertilization with the palisade grass (Brachiaria brizantha cv. Marandu) in sandy clayey Oxisol with low phosphorus content.

\section{Material and methods}

The experiment was performed in a plant nursery of the Federal University of Mato Grosso, Campus of Rondonópolis. For all evaluated variables, with exception of dry mass of residue and roots, the experimental design was completely randomized, with eight replications, in a split-plot scheme. As there was a single collection of roots and residue, the completely randomized design with eight replications was adopted.

The parcels consisted in six fertilization treatments of the palisade grass, with four treatments applied in the presence of liming and two in its absence. The treatments applied in the presence of liming were: (1) single superphosphate and urea, (2) single superphosphate and ammonium sulfate, (3) reactive natural phosphate and urea, (4) reactive natural phosphate and ammonium sulfate. The treatments applied in the absence of liming were: (5) reactive natural phosphate and urea, (6) reactive natural phosphate and ammonium sulfate. The split-plots consisted in the evaluation of three growth periods, being the first period evaluated 30 days after emergence of the palisade grass, and the remaining periods evaluated 20 days after the previous evaluation.

The compositions of the utilized fertilizers were: reactive natural phosphate $\left(29 \% \mathrm{P}_{2} \mathrm{O}_{5} ; 32 \%\right.$ $\mathrm{Ca})$, single superphosphate $\left(20 \% \mathrm{P}_{2} \mathrm{O}_{5}, 17 \% \mathrm{Ca}\right.$, $11 \% \mathrm{~S})$, urea $(46 \% \mathrm{~N})$, ammonium sulfate $(21 \%$ $\mathrm{N}, 24 \% \mathrm{~S})$ and potassium chloride $\left(58 \% \mathrm{~K}_{2} \mathrm{O}\right)$. The reactive natural phosphate presented $14 \%$ of soluble phosphorus in citric acid.

Each experimental unit consisted in a vessel with capacity of $5,0 \mathrm{dm}^{3}$ containing five plants. The utilized soil was an Oxisol with sandy clayey textural class (Table 1), collected in the layer of 0 to $0,20 \mathrm{~m}$, in native Cerrado (tropical savanna), in the region of the Rondonópolis municipality, whose chemical and granulometric characterization was performed according with the EMBRAPA (1997). After the collection, the soil was sieved in a $4 \mathrm{~mm}$ mesh and transferred to the vessels. The bases saturation was elevated to $40 \%$ (Vilela et al., 2004), with the incorporation of dolomitic limestone (PRNT= 80,3\%), which reacted for 30 days, with the humidity of the soil maintained at $80 \%$ of the maximum capacity of water retention in the soil. In this very moment, in the treatments without liming, the incubation of the reactive natural phosphate was performed.

Table 1. Granulometric and chemical characterization, with respective interpretation, of Oxisol with sandy clayey textural class.

\begin{tabular}{|c|c|c|c|c|c|c|c|c|c|c|c|c|}
\hline $\mathrm{pH}$ & P & K & $\mathrm{Ca}$ & $\mathrm{Mg}$ & $\mathrm{Al}$ & $\mathrm{H}$ & CEC & V & $\mathrm{m}$ & Sand & Silt & Clay \\
\hline $\mathrm{CaCl}_{2}$ & & $\mathrm{~m}^{-3}$ & & \multicolumn{3}{|c|}{$\mathrm{cmol}_{\mathrm{c}} \mathrm{dm}^{-3}$} & \multicolumn{4}{|c|}{$\%$} & \multicolumn{2}{|c|}{$\mathrm{g} \mathrm{kg}^{-1}$} \\
\hline 4.1 & 1.1 & 47 & 0.2 & 0.1 & 1.0 & 4.7 & 6.1 & 6.9 & 70.4 & 575 & 50 & 375 \\
\hline- & $\mathrm{VL}$ & A & VL & VL & - & - & A & $V L$ & $\mathrm{H}$ & - & - & - \\
\hline
\end{tabular}

The evaluation of the maximum water retention capacity of the soil was performed according with the described by Bonfim-Silva et al. (2011), with a modification in the moment of drainage of the vessels, in which they were covered with PVC cling film to avoid losses due to evaporation.
After the incubation period of the soil with limestone, for the correction of the soil acidity, the implantation fertilization was performed, consisting in the application of phosphorus and micronutrients. The applied phosphorus dosage $\left(\mathrm{P}_{2} \mathrm{O}_{5}\right)$ was of $300 \mathrm{mg} \mathrm{dm}^{-3}$, and single superphosphate and reactive natural phosphate 
were utilized, according with the treatments. The basic fertilization with the micronutrients was performed according with Bonfim-Silva \& Monteiro (2010).

After the implantation fertilization the sowing of the palisade grass cv. Marandu was performed, with 25 seeds per vessel. After the emergence of the plantlets a thinning was performed, allowing five plants per vessel. The criterium for the thinning was based on the strength and uniformity of the plantlets. After the thinning, the nitrogen and potassium $\left(\mathrm{K}_{2} \mathrm{O}\right)$ fertilization was performed, in the dosages of 200 and $100 \mathrm{mg} \mathrm{dm}^{-3}$, respectively. For the nitrogen supply were utilized the fertilizers described in the treatments, and the potassium in the form of potassium chloride. In the first growth, the fertilization with nitrogen and potassium was parceled into four equal applications to avoid an elevated osmotic pressure, as referred by Batista \& Monteiro (2008).

Thirty days after emergence, the SPAD (Soil Plant Analysis Development) was measured, performed the counting of the number of leaves and tillers and the cutting of the shoot part of the plant, which was made at $10 \mathrm{~cm}$ from the soil. The SPAD reading was performed with a portable chlorophyll meter in five diagnostic leaves per experimental parcel. The diagnostic leaves correspond to the two newest and completely expanded leaves. Were counted all leaves which were above the cut height and all present tillers in the vessels. After the cutting, the shoot part was separated in leaf blades and stem+sheath, being these fractions packed in paper bags, and later subjected to drying in hot air circulating oven at $65^{\circ} \mathrm{C}$ for 72 hours (Silva \& Queiroz, 2002), and lately weighed. This proceeding was repeated in the evaluation of the second and third growth, which occurred 20 days after the previous evaluations.

After each cutting, the fertilization with nitrogen and potassium was re-applied, in dosages of 200 and $100 \mathrm{mg} \mathrm{dm}^{-3}$, respectively, with the same mentioned sources. In all cuttings, soil samples were collected for $\mathrm{pH}$ analysis in calcium chloride, according with the methodology proposed by EMBRAPA (1997). In the third growth evaluation, besides the same proceeding of the previous cuttings, were collected the residue and root mass. The residue mass is the vegetal mass present under the cut height. The roots were sieved in a $4 \mathrm{~mm}$ mesh and washed. All the collected material was subjected to drying in hot air circulating oven at $65^{\circ} \mathrm{C}$ for 72 hours and lately weighed.

The evaluated variables were: dry masses of shoot, leaf blades, stem+sheath, residue and roots; number of leaves, tillers, SPAD and soil $\mathrm{pH}$. The results were subjected to the tests of Lilliefors (residues normality) and Cochran (variance homogeneity). As there was residues normality and the variances homogeneity for all variables, variance analysis was performed. In case of statistical difference within treatments, the means clustering test of Scott Knott was performed at 5\% probability. In order to measure the association between the variables and the $\mathrm{pH}$ of the soil, the t test for the Pearson correlation coefficient was utilized, with $5 \%$ probability.

\section{Results and Discussion}

There was significant interaction $(p<0,05)$ between treatments and growth periods for all evaluated variables in a split-plot scheme subdivided in time. In the first growth, the highest shoot dry mass and leaf blades was observed when the palisade grass cv. Marandu was fertilized with single superphosphate and ammonium sulfate in the presence of liming. (Table 2). However, there was no difference between the number of leaves and tillers of the grasses fertilized with single superphosphate associated to urea and ammonium sulfate.

The higher production of the palisade grass fertilized with single superphosphate, in the first growth, occurred because the supply of a source with phosphorus readily available for absorption is important for the establishment of the grasses (Maciel et al., 2007), since that phosphorus in the most required nutrient in the implantation of forage grasses (Cantarutti et al., 1999). Higher productions of grasses fertilized with soluble sources of phosphorus were observed in several scientific works (Harger et al., 2007; Santos et al., 2009; Sousa e Korndörfer, 2011, Schoninger et al. 2013). This better development of soluble sources of phosphorus compared with the reactive natural phosphates occurs mainly 
because the soluble fertilizers increase, in short term, the contents of available phosphorus (Luchini et al., 2012), being this nutrient indispensable in the establishment of the root system (Rezende et al., 2011).

Table 2 Dry masses of shoot, leaf blades, stem+sheath, number of tillers and leaves of the palisade grass cv. Marandu subjected to fertilization with phosphate and nitrogen fertilizers in three growth periods.

\begin{tabular}{|c|c|c|c|c|c|c|}
\hline \multirow{2}{*}{ Treatments } & \multicolumn{4}{|c|}{ Liming } & \multicolumn{2}{|c|}{ No liming } \\
\hline & SSP AM & SSP UR & NF AM & NF UR & NF AM & NF UR \\
\hline & \multicolumn{6}{|c|}{ Shoot dry mass (g vessel-1) } \\
\hline $1^{\circ}$ growth & $16.89 a C$ & $13.30 \mathrm{bc}$ & $5.21 \mathrm{CB}$ & $0.10 \mathrm{dC}$ & $12.20 \mathrm{bB}$ & $4.68 \mathrm{CB}$ \\
\hline $2^{\circ}$ growth & $36.79 \mathrm{aA}$ & $28.66 \mathrm{bA}$ & $34.21 \mathrm{aA}$ & $5.79 \mathrm{~dB}$ & $30.21 \mathrm{bA}$ & $16.36 \mathrm{cA}$ \\
\hline \multirow{3}{*}{$\begin{array}{l}3^{\circ} \text { growth } \\
\text { CV (\%): } 9.87\end{array}$} & $27.11 \mathrm{aB}$ & $20.98 \mathrm{bB}$ & $30.38 \mathrm{aA}$ & $19.56 \mathrm{bA}$ & $3.00 \mathrm{dC}$ & $13.64 \mathrm{cA}$ \\
\hline & & & & & & \\
\hline & \multicolumn{6}{|c|}{ Leaf blades dry mass (g vessel-1) } \\
\hline $1^{\circ}$ growth & $14.67 \mathrm{aC}$ & $11.48 \mathrm{bC}$ & $4.58 \mathrm{CB}$ & $0.10 \mathrm{dC}$ & $11.12 \mathrm{bB}$ & $4.06 \mathrm{CB}$ \\
\hline $2^{\circ}$ growth & $32.06 \mathrm{aA}$ & $23.85 \mathrm{bA}$ & $28.72 \mathrm{aA}$ & $5.00 \mathrm{~dB}$ & $26.74 \mathrm{bA}$ & $14.53 \mathrm{cA}$ \\
\hline \multirow{3}{*}{$\begin{array}{l}3^{\circ} \text { growth } \\
\text { CV (\%): } 9.36\end{array}$} & $22.60 \mathrm{aB}$ & $18.06 \mathrm{bB}$ & $25.44 \mathrm{aA}$ & $15.85 \mathrm{bA}$ & $2.51 \mathrm{dC}$ & $11.94 \mathrm{CA}$ \\
\hline & & & & & & \\
\hline & \multicolumn{6}{|c|}{ Stem+sheath dry mass ( $\mathrm{g}$ vessel $^{-1}$ ) } \\
\hline $1^{\circ}$ growth & $2.22 \mathrm{aB}$ & $1.83 \mathrm{aB}$ & $0.63 \mathrm{bB}$ & $0.00 \mathrm{cB}$ & $1.08 \mathrm{bB}$ & $0.62 \mathrm{bB}$ \\
\hline $2^{\circ}$ growth & $4.73 \mathrm{aA}$ & $4.81 \mathrm{aA}$ & $5.49 \mathrm{aA}$ & $0.78 \mathrm{~dB}$ & $3.48 \mathrm{bA}$ & $1.82 \mathrm{cA}$ \\
\hline \multirow{3}{*}{$\begin{array}{l}3^{\circ} \text { growth } \\
\text { CV (\%): } 12.99\end{array}$} & $4.50 \mathrm{aA}$ & $2.92 \mathrm{~b} \mathrm{~B}$ & 4.94 a A & $3.71 \mathrm{~b} \mathrm{~A}$ & $0.49 \mathrm{~dB}$ & $1.70 \mathrm{cA}$ \\
\hline & & & & & & \\
\hline & \multicolumn{6}{|c|}{ Tillers vessel-1 $^{-1}$} \\
\hline $1^{\circ}$ growth & $43.75 \mathrm{aC}$ & $35.60 \mathrm{aC}$ & $22.71 \mathrm{bC}$ & $8.80 \mathrm{cC}$ & $41.83 \mathrm{aA}$ & $21.00 \mathrm{bC}$ \\
\hline $2^{\circ}$ growth & $63.12 \mathrm{aB}$ & $47.60 \mathrm{bB}$ & $49.00 \mathrm{bB}$ & $23.60 \mathrm{~dB}$ & $45.67 \mathrm{bA}$ & $35.62 \mathrm{CB}$ \\
\hline \multirow{3}{*}{$\begin{array}{l}3^{\circ} \text { growth } \\
\mathrm{CV}(\%): 7.71\end{array}$} & $84.12 \mathrm{aA}$ & $71.60 \mathrm{bA}$ & $72.00 \mathrm{bA}$ & $42.80 \mathrm{dA}$ & $34.17 \mathrm{eB}$ & $51.50 \mathrm{cA}$ \\
\hline & & & & & & \\
\hline & \multicolumn{6}{|c|}{ Leaves vessel $^{-1}$} \\
\hline $1^{\circ}$ growth & $119 a C$ & $97 \mathrm{aC}$ & $57 \mathrm{bC}$ & $5 \mathrm{cC}$ & $104 \mathrm{aB}$ & $61.88 \mathrm{bC}$ \\
\hline $2^{\circ}$ growth & $185 \mathrm{aB}$ & $134 \mathrm{bB}$ & $173 a B$ & $56 \mathrm{~dB}$ & $164 \mathrm{aA}$ & $89.00 \mathrm{cB}$ \\
\hline $3^{\circ}$ growth & $236 \mathrm{aA}$ & $217 \mathrm{aA}$ & $252 \mathrm{aA}$ & $156 \mathrm{bA}$ & $84 \mathrm{cC}$ & $167.75 \mathrm{bA}$ \\
\hline CV (\%): 9.76 & & & & & & \\
\hline
\end{tabular}

Associated to the single superphosphate, the ammonium sulfate provides sulfur, important for protein synthesis, seen that the simultaneous ministration of nitrogen and sulfur, in the proportions from 7:1 to 11:1, contributes for the recovery of the decumbens grass (Brachiaria), increases the leaf area, the production of dry mass and increases the efficiency in the use of water (Bonfim-Silva et al., 2007).

In the first growth, it was observed that the palisade grass cv. Marandu, cultivated in soil with liming and fertilized with single superphosphate and urea had the same production of shoot part and leaf blades of the grass cultivated in soil without liming and fertilized with reactive natural phosphate and ammonium sulfate. This demonstrates that the natural acidity of the Oxisol (Table 1) associated to the acidification resultant from the nitrification of the ammonium (Table 3 ) in the soil is capable to achieve that the reactive natural phosphate reaches the same efficiency of a soluble source of phosphorus. Even observing promising results of the reactive natural phosphate in naturally acid soils, liming is a practice which must be adopted even in aciditytolerant crops, such as the forage plants of the Brachiaria genus. Liming reduces the solubility of cationic micronutrients, avoiding the occurrence of toxicity and increasing the CEC of the soil, what elevates the efficiency of the fertilization and mitigates the occurrence of lixiviation of essential nutrients, such as nitrogen (ammonium), potassium, calcium and magnesium.

In the first growth, in presence or absence of liming, the reactive natural phosphate associated to the ammonium sulfate provided a higher shoot dry mass, leaf blades, number of leaves and tillers of the palisade grass cv. Marandu, comparing the association of the same phosphate fertilizer and urea (Table 2). A lower 
soil pH was observed in the treatments fertilized with ammonium sulfate (Table 3), what possibly favored the solubilization of the reactive natural phosphate, since that soil acidity enables the solubilization of this fertilizer (Guedes et al., 2009).

Table 3. $\mathrm{pH}$ means of the soil cultivated with palisade grass cv. Mrandu subjected to fertilization with phosphate and nitrogen sources during three growth periods.

\begin{tabular}{lcccccc}
\hline \multirow{2}{*}{ Treatments } & \multicolumn{4}{c}{ Liming } & \multicolumn{2}{c}{ No liming } \\
\cline { 2 - 7 } & SSP AM & SSP UR & NF AM & NF UR & NF AM & NF UR \\
\hline $1^{\circ}$ growth & $4.16 \mathrm{~d} \mathrm{~A}$ & $5.37 \mathrm{a} \mathrm{A}$ & $4.97 \mathrm{~b} \mathrm{~A}$ & $5.76 \mathrm{a} \mathrm{A}$ & $3.73 \mathrm{~d} \mathrm{~A}$ & $4.62 \mathrm{c} \mathrm{A}$ \\
$2^{\circ}$ growth & $3.93 \mathrm{C} \mathrm{A}$ & $5.05 \mathrm{a} \mathrm{A}$ & $3.95 \mathrm{c} \mathrm{B}$ & $4.83 \mathrm{a} \mathrm{B}$ & $3.72 \mathrm{C} \mathrm{A}$ & $4.40 \mathrm{~b} \mathrm{~A}$ \\
$3^{\circ}$ growth & $3.59 \mathrm{c} \mathrm{B}$ & $4.69 \mathrm{a} \mathrm{B}$ & $3.19 \mathrm{c} \mathrm{C}$ & $5.08 \mathrm{a} \mathrm{B}$ & $3.82 \mathrm{~b} \mathrm{~A}$ & $4.14 \mathrm{~b} \mathrm{~A}$ \\
CV(\%): 5.28 & & & & & &
\end{tabular}

SSP AM: single superphosphate and ammonium sulfate, SSP UR: single superphosphate and urea, NF AM: reactive natural phosphate and ammonium sulfate, NF UR: reactive natural phosphate and urea. CV (\%): coefficient of variation. Means followed by the same uppercase letter, on the column, and lowercase, on the line, do not differ through the test of Scott Knott $(p>0,05)$.

Although both nitrogen fertilizers do acidify the soil due to the occurrence of nitrification, it was observed, in the soils fertilized with urea, that higher $\mathrm{pH}$ values occurred (Table 3), what might have minimized the solubilization of the reactive natural phosphate. Simillar results were observed (Sangoi et al. 2009; Sousa \& Silva, 2009), and the lower acidification of the soil fertilized with urea occurs due to the loss of ammonia through volatilization, leading to smaller quantities of available ammonium for nitrification, which is a process that releases hydrogens to the soil (Barbosa Filho et al., 2005).

Another hypothesis for the lower acidification of the soil by urea, comparatively to the ammonium sulfate, is that urea reacts in the soil, releasing hydroxyls and/or removing hydrogens from the soil (Mantovani et al., 2007), what initially increases the soil pH. Kiehl (1989) observed increments in the soil pH from 4,8 to 6,6 and 6,0 to 7,1 in Neosol and Nitisol, respectively, close to urea granule.

In the second and third growths, the shoot dry mass of the palisade grass cv. Marandu fertilized with reactive natural phosphate and ammonium sulfate equaled that observed in the fertilization with single superphosphate and ammonium sulfate, and was higher than the dry mass observed in the grass fertilized with single superphosphate and urea, being all these treatments applied in soil with liming. It might be observed that the acidity of the soil, originated from the ammonium sulfate, allows the use of reactive natural phosphate even after the practice of liming.

In the first growth, the lowest SPAD value was observed in the palisade grass cultivated in soil with liming, fertilized with reactive natural phosphate and urea (Table 4). The possible influence of phosphorus in the SPAD value is associated with the energetic expenditure in the nitrogen assimilation by the plants. The nitrate absorbed by the roots must be reduced to ammonium so that nitrogen might be incorporated to the chains of amino acids, and this assimilation occurs with energetic expenditure (Bloom et al., 1992), that is, with the use of adenosine triphosphate (ATP), which possesses phosphorus in its structure, and might have been limiting by the use of reactive natural phosphate in the soil with highest $\mathrm{pH}$ (Table 3).

In the second and third cuttings of the forage grass, the highest SPAD values were observed in the grasses cultivated in soil with liming, and fertilized with single superphosphate and ammonium sulfate, and reactive natural phosphate associated with both nitrogen fertilizers (Table 4). However, only the single superphosphate and the reactive natural phosphate, when associated with the ammonium sulfated, allowed to aggregate an elevated production of shoot dry mass (Table 2) and highest SPAD value, that is, elevated concentration of nitrogen, once that the SPAD and the concentration of nitrogen present a positive correlation (Cabral et al., 2013).

The same dry mass of roots occurred between the treatments fertilized with single superphosphate and those fertilized with reactive natural phosphate and ammonium sulfate (Table 5), although a difference has been observed in the production of the shoot part of the plants. This is justified by the variation in the collected data (CV: $32,81 \%$ ), and this variation might have 
occurred due to methodological difficulty of roots collection through sieving, through which the thinner roots are lost. Another possibility lies in the difference between the roots mass and effective roots mass in the absorption of nutrients, what might indicate that different root masses might absorb same quantities of nutrients, or even equal masses might absorb different quantities of nutrients, since that the roots which possess exoderm present hydrophobic material, reducing the permeability to water (Holbrook, 2004).

Concerning the dry mass of residue, there was the same production within the grasses fertilized with single superphosphate and those fertilized with reactive natural phosphate and ammonium sulfate (Table 4). The dry mass of roots and of residue is associated to the resprout potential of the forage grasses, since that the roots and the base of the stem present organic reserves of carbohydrates and become a source in the source-drain relation when there is limitation of the residual leaf area (Rodrigues et al., 2007), which occurs after the cut of the grass. Furthermore, the residue is the portion of the grass which presents residual leaf area and basal and lateral buds for an adequate re-sprout of the grass.

A significant negative correlation was observed $(p<0,01)$ within the $\mathrm{pH}$ of the soil and all evaluated variables, except for the SPAD value. Therefore, there occurs association between the $\mathrm{pH}$ of the soil and the production of dry masses of shoot part $(r=-0,43)$, leaf blades $(r=-0,42)$, stem+sheath $(r=-0,42)$, number of leaves $(r=-0,57)$ and of tillers $(r=-0,58)$ of the palisade grass $\mathrm{cv}$. Marandu. Therefore, as the $\mathrm{pH}$ of the soil decreased, an increase occurred in the production, and vice-versa. This correlation corroborates with the data provided by Guedes et al. (2009), in which the increase in the efficiency of reactive natural phosphates associates to the reduction in the $\mathrm{pH}$ of the soil.

Table 4. Means of the SPAD value, dry mass of residue and roots of the palisade grass cv. Marandu subjected to fertilization with phosphate and nitrogen sources during three growth periods.

\begin{tabular}{|c|c|c|c|c|c|c|}
\hline \multirow{2}{*}{ Treatments } & \multicolumn{4}{|c|}{ Liming } & \multicolumn{2}{|c|}{ No liming } \\
\hline & SSP AM & SSP UR & NF AM & NF UR & NF AM & NF UR \\
\hline & & \multicolumn{5}{|c|}{ SPAD } \\
\hline $1^{\circ}$ growth & 56.41 a A & 54.30 a A & 54.16 a A & $30.40 \mathrm{~b} \mathrm{C}$ & 54,77 a A & $51.15 \mathrm{aA}$ \\
\hline $2^{\circ}$ growth & 48.05 a B & $40.92 \mathrm{~b} \mathrm{~B}$ & 53.08 a A & $50.50 \mathrm{a} \mathrm{B}$ & $45,94 \mathrm{~b} B$ & $42.61 \mathrm{~b} \mathrm{~B}$ \\
\hline $3^{\circ}$ growth & 58.01 a A & $53.61 \mathrm{~b} \mathrm{~A}$ & 58. $25 a \mathrm{~B}$ & $58.60 \mathrm{a} \mathrm{A}$ & $52.02 \mathrm{~b} \mathrm{~A}$ & $49.38 \mathrm{~b} \mathrm{~A}$ \\
\hline \multicolumn{7}{|l|}{$C \vee(\%): 3.69$} \\
\hline & & \multicolumn{5}{|c|}{ Residue dry mass (g vessel-1) } \\
\hline \multirow[t]{2}{*}{ CV(\%): 17.39} & $71.70 \mathrm{a}$ & $58.19 \mathrm{a}$ & $54.02 \mathrm{a}$ & $22.84 \mathrm{~b}$ & $33.40 \mathrm{~b}$ & $31.83 \mathrm{~b}$ \\
\hline & & \multicolumn{5}{|c|}{ Roots dry mass (g vessel-1) } \\
\hline CV $(\%): 32.81 \%$ & $32.89 \mathrm{a}$ & $29.28 \mathrm{a}$ & $30.72 \mathrm{a}$ & $10.72 \mathrm{~d}$ & & $17.74 \mathrm{C}$ \\
\hline
\end{tabular}

\section{Conclusion}

The ammonium sulfate enables the use of reactive natural phosphate, after the liming, in the fertilization of the palisade grass cv. Marandu, in sandy clayey Oxisol with low phosphorus content, whilst urea does not provide sufficient soil acidity for the use of this fertilizer.

\section{References}

Barbosa Filho, M.P., Fageria, N.K., Silva, O.F. 2005. Fontes, doses e parcelamento da adubação nitrogenada em cobertura para feijoeiro comum irrigado. Ciência e Agrotecnologia 29:69-76.
Batista, K., Monteiro, F.A. 2008. Nitrogênio e enxofre nas características morfogênicas do capim-marandu em substituição ao capimbraquiária em degradação em solo com baixo teor de matéria orgânica. Revista Brasileira de Zootecnia 37:1151-1160.

Bloom, A.J., Sukrapanna, S.S., Warner, R.L. 1992. Root respiration associated with ammonium and nitrate absorption and assimilation by barley. Plant Physiology 99:1294-1301.

Bonfim-Silva, E.M., Monteiro, F.A., Silva. T.J.A. 2007. Nitrogênio e enxofre na produção e no uso de água pelo capim-braquiária em degradação. Revista Brasileira de Ciência do Solo 31:309-317. 
Bonfim-Silva, E.M., Monteiro, F.A. 2010. Nitrogênio e enxofre na adubação e em folhas diagnósticas e raízes do capim-braquiária em degradação. Revista Brasileira de Zootecnia 39:1641-1649.

Bonfim-Silva, E.M., Silva, T.J.A., Cabral, C.E.A., Kroth, B.E., Rezende D. 2011. Desenvolvimento inicial de gramíneas submetidas ao estresse hídrico. Revista Caatinga 24:180-186.

Cabral, C.E.A., Abreu, J.G., Bonfim-Silva, E.M., Cabral, C.H.A., Scaramuzza, J.F., Silva, T.J.A. 2013. Eficiência de produção e concentração de nitrogênio nos capins marandu, decumbens e convert submetidos à adubação nitrogenada. Bioscience Journal 29:1653-1663.

Cantarutti, R.B., Martinez, H.E.P., Carvalho, M.M., Fonseca, D.M., Arruda, A.L., Vilela, H., Oliveira, F.T.T. 1999. Pastagens. In: Ribeiro, A.C., Guimarães, P.T.G. Alvarez V., V.H. (Eds). Recomendação para o uso de corretivos e fertilizantes em Minas Gerais. $5^{a}$ aproximação. CFSEMG, Viçosa, Brazil, p.43-60.

Cessa, R.M.A., CELI, L., Vitorino, A.C.T., Novelino, J.O., Barberis, E. 2009. Área superficial específica, porosidade da fração argila e adsorção de fósforo em dois Latossolos Vermelhos. Revista Brasileira de Ciência do Solo 33:1153-1162.

Delbem, F.C., Scabora, M.H., Soares Filho, C.V., Heinrichs, R., Crociolli, C.A., Cassiolato, A.M.R. 2011 . Fontes e doses de adubação nitrogenada na atividade microbiana e fertilidade do solo cultivado com Brachiaria brizantha. Acta Scientiarum. Agronomy 33:361-367.

Eberhardt, D. N., Vendrame, P. R. S., Becquer, T., Guimarães, M. F. 2008. Influência da granulometria e da mineralogiasobre a retenção do fósforo em Latossolos sob pastagens no Cerrado. Revista Brasileira de Ciência do Solo 32:1009-1016.

Embrapa - Empresa Brasileira de Pesquisa Agropecuária. 1997. Manual de métodos de análises de solo. Centro Nacional de Levantamento e Conservação do Solo. Embrapa Solos, Rio de Janeiro, Brazil. 212p.

Guedes, E.M., Fernandes, A.R., Lima, E.V., Gama, M.A.P., Silva, A.L.P. 2009. Fosfato natural de arad e calagem e o crescimento de Brachiaria brizanta em Latossolo Amarelo sob pastagem degradada na Amazônia. Revista de Ciências Agrárias 52:117-129.

Harger, N., Brito, O.R., Ralisch, R., Ortiz, F.R., Watanabe, T.S. 2007. Avaliação de fontes e doses de fósforo no crescimento inicial do milho. Semina: Ciências Agrárias 28:39-44.

Holbrook, N. M. Balanço hídrico das plantas. 2004. In: Taiz, L., Zeiger, E. Fisiologia vegetal. 3 ed. ARTMED, Porto Alegre, Brazil. p. 75-93
Kaminski, K., Mello, F.A.F. 1984. Época de aplicação de fosfatos em relação ao calcário no suprimento de fósforo ao sorgo. Revista Brasileira de Ciência do Solo 8:297-300.

Kiehl, J.C. 1989. Distribuição e retenção da amônia no solo após a aplicação de ureia. Revista Brasileira de Ciência do Solo 13:75-80.

Luchini, I., Tiritan, C.S., Foloni, J.S.S., Santos, D.H. 2012. Fósforo disponível em solos ácidos e corrigidos com aplicação de fosfatos solúvel, reativo e natural. Scientia Agraria Paranaenis $11: 82-94$.

Maciel, G.A., Costa, S.E.G.V.A., Furtini Neto, A.E., Ferreira, M.M., Evangelista, A.R. 2007. Efeito de diferentes fontes de fósforo na Brachiaria brizantha cv. Marandu cultivada em dois tipos de solos. Ciência Animal Brasileira 8:227-233.

Mantovani, A., Ernani, P.R., Sangoi, L. 2007. A adição de superfosfato triplo e a percolação de nitrogênio no solo. Revista Brasileira de Ciência do Solo $31: 887-895$.

Rezende, A.V., Lima, J.F., Rabelo, C.H.S., Rabelo, F.H.S., Nogeira, D.A., Carvalho, M., Faria Junior, D.C.N.A., Barbosa, L.A. 2011. Características morfofisiológicas da Brachiaria brizantha $\mathrm{cv}$. Marandu em resposta à adubação fosfatada. Revista Agrarian 4:335-343.

Rodrigues, R.S., Mourão, G.B., Valinote, A.C., Herling, V.R. 2007. Reservas orgânicas, relação parte aérea-raiz e C-N e eliminação do meristema apical no capim-xaraés sob doses de nitrogênio e potássio. Ciência Animal Brasileira 8:505-514.

Sangoi, L., Ernani, P.R. Bianchet, O. 2009. Desenvolvimento inicial do milho em função de doses e fontes de nitrogênio aplicadas na semeadura. Biotemas 22:53-58.

Santos, V.R., Moura-Filho, G., Albuquerque, A.W., Costa, J.P.V., Santos, C.G., Santos, A.C.I. 2009. Crescimento e produtividade agrícola de cana-de-açúcar em diferentes fontes de fósforo. Revista Brasileira de Engenharia Agrícola e Ambiental 13:389-396.

Schoninger, E. L., Gatiboni, L. C., Ernani, P. R. 2013. Fertilização com fosfato natural e cinética de absorção de fósforo de soja e plantas de cobertura do cerrado. Semina: Ciências Agrárias 34:95-106.

Silva, D.J., Queiroz, A.C. 2002. Análise de alimentos: Métodos químicos e biológicos. 3. ed. UFV, Viçosa, Brazil. 235p.

Sousa, R.A., Silva, T.R.B. 2009. Acidificação de um Latossolo Vermelho Distroférrico em função da aplicação de nitrogênio oriundo de ureia, sulfato 
de amônio e sulfammo. Cultivando o Saber 2:78-

83.

Sousa, R.T X., Korndörfer, G.H. 2011. Efeito da aplicação de fertilizantes fosfatados na produtividade e variáveis tecnológicas da canade-açúcar. Enciclopédia Biosfera 7:1-10.

Vilela, L., Soares, W.V., Sousa, D.M.G. Calagem e adubação para pastagens. In: Sousa, D.M.G., Lobato, E. Cerrado: correção do solo e adubação. 2. ed. Embrapa, Brasília, Brazil. p. 367382. 